\title{
Called to the ministry: Narratives of career choice amongst female pastors in South Africa
}

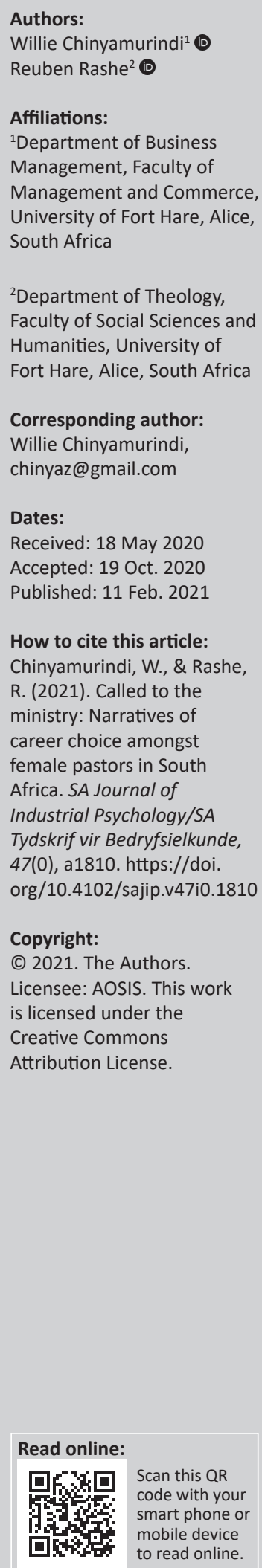

Orientation: There is a noted entrance of females into careers that have been a preserve traditionally of males. One such cohort needing understanding concerns females entering the pastoral ministry.

Research purpose: The study explores the career choice issues of female pastors into the pastoral ministry.

Motivation of the study: Calls have been made within the local and international literature for studies that give attention to understanding issues related to career development through the prism of calling, faith and religiosity.

Research approach, design and method: A narrative inquiry using a sample of 15 females who have studied for the pastoral ministry within a leading Christian protestant denomination was utilised.

Main findings: Three main narratives emerged. First, the entrance to the pastoral ministry as an answer to the voice of God and also made clear through signs from God. Second, an entrance to the pastoral ministry is a result of support from significant others. Finally, an entrance to the pastoral ministry is due to the need to challenge the status quo and give more female representation to a perceived gendered space, the church.

Practical/managerial implications: Career counsellors may need to be aware of the issues that surround females entering careers often classified not their own. Strategies can be proposed based on such an understanding within contemporary career counselling practice.

Contribution/value-add: This study contributes to the growing body of knowledge, focusing on the need to understand how issues of calling, faith and religiosity affect individual career choice and, subsequently, career development.

Keywords: South Africa; female; pastors; career choice; ministry.

\section{Introduction}

There is a noted shift in society, characterised often by women's entry, especially in careers that may traditionally be the domain of men. This shift may be responsible for challenging the old order of thinking. For instance, Cooper (1995)'s values of 'strength, robustness, boldness, stoutness, bravery' (pp. 146-147) may be questioned as to their relevance to men alone. Some (e.g. Gagnon \& Sandoval, 2020) argue for the need to question the relevance in contemporary society of gender stereotyping with their argument being for the need for inclusivity as is being performed in the career paths in the sciences and technology. Part of this process concerns exploring pay differences between women and men (Albrecht, Bronson, Thoursiec, \& Vroman, 2018). The process also entails understanding continually those barriers affecting the career development of minority groups such as women.

In South Africa, there is noted work from scholars who explored the entry of women in sport such as bodybuilding and also the ensuing opportunity (Khubisa \& Reddy, 2017). This entry of women into male-dominated areas may also potentially come with complexity, especially for the women (Hasunuma, 2019). The complexity here could involve how women deal with barriers that affect their progression (Bannister \& Moyi, 2019). These challenges can be rooted in religious and social systems and limit their expression in such systems (Womack, Duncan, \& Pillay, 2020). In essence, females' career experiences significantly differ from their male counterparts (Hancock \& Hums, 2016). 
In the African continent and in South Africa, there is growing recognition of pastors' importance as societal agents. A clarion call has been made to policy makers and 'Westerntrained health care practitioners' to view pastors as important experts who can assist in solving community challenges (Masola, Sigida, \& Khorommbi, 2019, p. 1). Emphasis is also placed on understanding the female pastor's role and the challenges experienced in their vocation (Mupangwa \& Chirongoma, 2020). Further, there is a need for more empirical efforts that also explore the resolution experiences of female pastors working in a profession deemed a dominantly male domain (Mujinga, 2020). This becomes critical in addressing barriers female pastors face, especially in South Africa, which remain under-explored within the extant literature (Nyabvudzi \& Chinyamurindi, 2019). A starting point to this can be understanding issues that inform career entry into such professions (Chinyamurindi, 2016a) and further exploring how these manifest in adulthood given individual, organisational and societal constraints (Nyabvudzi \& Chinyamurindi, 2020). The experience of women as a minority group yet alone in the pastoral ministry provides an interesting sample group and context to understand all this.

There is also emphasis on the pastoral ministry's role, defined as an influential position where a person leads and takes care of a church congregation (Wright et al., 2019). The pastor's role may also offer congregants emotional support, given the many hardships faced (Hope, Assari, Cole-Lewis, \& Caldwell, 2017). This can be through providing counselling (Hoga, Rodolpho, Penteado, Borges, \& Alvarez, 2013). Within such religious systems, challenges exist, the most notable being the role and positioning of women to positions of spiritual authority (Oom-Dove, 2018).

In all this reviewed work, it is interesting to note how aspects of intersectionality feature. Calls exist in the literature for scholars to search for 'nuances and new directions' especially relating to how issues of gender, sex and religiosity intersect in general (Robertson, 2017). The thinking here could be that aspects of faith, calling, spirituality and religiosity are important parts of individuals' private and public lived experience (Amoateng, 2020; ed. Ewest, 2018). As Burger, Crous and Roodt (2012) advocated, there is a need to understand how the search for meaning occurs, especially within the confines of change. Specific to gender issues in South Africa, some notable trends can be flagged. Firstly, a breaking down of race and gender barriers by women (The South African Board for People Practices Women's Report, 2020) also aided by support from laws such as the Employment Equity Act No. 55 of 1998. This has allowed for the prioritisation and giving opportunities to women within the workplace. Secondly, there is also a noted societal shift, one that is open to issues related to women's advancement (Chinyamurindi, 2016b). Like the previous issue, this is also supported by legislative changes that are happening at a macro-scale. From the study's vantage, we note little or no empirical work focused on understanding these issues from a female pastor's lens. This is despite the acknowledged changes happening in the society.

Within the domain of work, beliefs and practices have been noted to feature (ed. Neal, 2013). Such a fusion between work and aspects of faith, calling, spirituality and religiosity can also shape attitudes and behaviours at an individual and collective level (LoRusso, 2018). This positions a need to understand aspects of faith, calling, spirituality and religiosity and how they impact individuals and organisations in general. This, in turn, positions the need for more studies that explore how female pastors serve in the pastoral ministry, including 'calling and experiences of these women' (Bumgardner, 2015, p. 40).

Such calls could fit into what some theologians in South Africa are calling a 'contextual awareness in ministerial formation' that 'challenges the current discourse', bearing in mind 'contextual dynamics' and avoiding 'oversimplification of the matter' (Womack, Duncan, \& Pillay, 2020, p. 1).

Another noted gap in the literature concerning aspects of faith, calling, spirituality and religiosity could be methodological. In South Africa, a predominant number of studies in this area have taken a purely positivist-quantitative survey design to understand such issues (e.g. Beukes \& Botha, 2013; Fouché, Rothmann, \& Van der Vyver, 2017; Willemse \& Deacon, 2015). Some effort deviation away from the predominant mode of inquiry in positivist-quantitative survey approaches can be noted as well (e.g. Koekemoer \& Mostert, 2010) though in the minority.

\section{Research purpose and objectives}

Calls exist within the empirical literature for studies that focus more on understanding the issues presented in this literature review, primarily on how calling, faith and religiosity affect individual career choice and subsequent career development. Thus, the main research question guiding the study was: What issues affect the career choice of female pastors into ministry?

\section{Literature review}

\section{Theoretical lens}

Concerning the theoretical underpinnings, the focus is on those theories specific to career advancement issues and those that concern how female pastors operate or navigate within this. The first general consideration here could be cosmopolitan feminism. Graham (1995, p. 13) positioned this as a 'body of theory and politics' that explores not only issues of women exclusion and subordination but the consideration of intersectionality from the role of 'society', 'the self' and from 'knowledge' sources. In research conducted in South Africa using female refugees, the assumption is that female pastors, by their lack of power, may fail to struggle not only in society but also in their 
careers considering aspects related to their gender and class (Nyabvudzi \& Chinyamurindi, 2019, 2020). In essence, there appears to be a culture of exclusion within the ministry against female pastors and it is mooted in tradition (Mupangwa \& Chirongoma, 2020). Extending and utilising the idea of cosmopolitan feminism, some women may seek to thrive under limiting conditions informed more by a sense of calling than perceived human-made impositions (Mujinga, 2020). Such a quest, despite exclusion and perceived subordination (including the desire to challenges status quo), can see female pastors' exercise a form of agency allowing them to develop an expert status or seeing the pastoral ministry to be a career path suited to an expert (Masola et al., 2019). An expert is not limited or defined by gender but by their knowledge and potential impact. These constructive tension features (Reilly, 2007) often lead to emancipatory spiritual practice ideals within individual functioning (Oom-Dove, 2018). The journey towards assisting others as an expert within the pastoral ministry for female pastors (Masola et al., 2019) can be thought of as having to begin through the individual navigating past their own personal challenges framed within the intersection of race, social class and gender (Oom-Dove, 2018). This allows, as framed with cosmopolitan feminism, consideration to the role not only of 'the self' but also 'knowledge' and the impact that this has on the other (Graham, 1995, p. 13).

A second consideration related to the careers literature could be the career construction theory (CCT) (Savickas, 2005). The emphasis here is placed on the role of social context and individual characteristics in shaping the career identity (Hancock \& Hums, 2016), especially for female pastors (Astin, 1984; Betz \& Fitzgerald, 1987). There could be an opportunity to even link ideals within feminist theory and the CCT to critical theory (Hancock \& Hums, 2016). The main idea allows for understanding social experience to address and identify the constraints imposed by dominant power structures (Kincheloe \& McLaren, 2002). For female pastors operating within the pastoral ministry, the focus is on how interlinkages between individual, societal and organisational processes can either support or impede quests for development in such professions (Mupangwa \& Chirongoma, 2020). Ideally, female pastors within the ministry can use their gender identity experience to develop the acumen to solve society's challenges (Masola et al., 2019). Such identification and the ensuing activity of making meaning to all this becomes a useful armoury in addressing individual and societal challenges (Mujingwa, 2020) and framing a possible path to these limitations (Nyabvudzi \& Chinyamurindi, 2019). In essence, CCT through the identity work happening to the individual can help inform an understanding of the factors influencing individual career development (Chinyamurindi, 2016a) and accounting for the role of gender (Nyabvudzi \& Chinyamurindi, 2020).

\section{Empirical literature}

A range of studies explores the career of women in maledominated professions.

Beigi, Nayyeri and Shirmohammadi (2020) in Tehran studied female pastors' career experiences in the internet taxi industry. The entrance into such careers was motivated by: (1) financial needs, (2) flexibility, (3) passion for driving and (4) the role of social relationships. Other studies position cultural variables as informing career choice and career development issues, especially influencing women (Wang, Holmes, Devine, \& Bishoff, 2019).

In black religious communities, parents have been found to play an important role in shaping teenagers' decisions, especially those parents who are churched (Wright et al., 2019). These identified factors fit into what has been referred to as the 'socio-emotional development' agenda that posits the role of community to include the schooling system, teachers and parents in assisting women entering into career paths where they are under-represented (Gagnon \& Sandoval, 2020, p. 1). In as much as society and family can be supportive, other studies posit that it is also potentially discouraging for women to enter certain jobs or careers (Mozahem, Ghanem, Hamieh, \& Shoujaa, 2019).

This may be the case in some communities; however, others (e.g. Phiri, 2009) note that education, especially theological education, is out of the majority of African female pastors' reach. The absence of access to theological education may limit female pastors' entrance in professions like the pastoral ministry, despite the presence of mentors and support systems that encourage them in such paths. This becomes critical as other studies have shown mentorship and inspirational leadership as critical in improving women's representation in professions where they are underrepresented (Abu-Hammad et al., 2020).

Some studies exploring responses to poor health challenges have found, as a coping mechanism, the role of support from a deity (God), family, friends and the church to be important (Iddrisu, Aziato, \& Dedey, 2019). The thinking here could be some form of allegiance and trust that an individual may have on a spiritual force or deity (Butler, 2007). Aspects of contestation appear to feature whenever women enter men's preserve, especially when it comes to career work. For instance, Khubisa and Reddy (2017), in their study of how religio-cultural ideals relate with women's bodies, attribute the problem to how certain roles and even physical features appear to be gendered. The general percetion here is for male pastors to occupy such roles and that exhibiting such physical features is normal. Nevertheless, when female pastors enter and practice in male-dominated areas, this is deemed atypical. Often, the support for such gendered bias can be used by some as a form of justified segregation. The behaviour here is to not only search for theological but also use biblical resources as part of work described by Jodamus (2017, p. 68) as 
'redemptive masculinities'. According to the Pew Research Center's 2018 report, the surprising part, especially within the Christian faith, is that more female pastors as compared to male pastors are viewed as religious (Cox \& Diamant, 2018).

Aspects such as a sense of calling are positively related to work attitudes (Willemse \& Deacon, 2015). The underlying argument here could be the role that context plays in affecting issues of calling, faith and religiosity. A point to note, though, with such research is how the focus and reporting are on a general measure of a sense of calling without capturing the influence of gender. Empirical attempts are being made to explore this influence by gender and yield mixed findings (Lazar, Davidovitch, \& Coren, 2016) despite noted gender (Sturges, 2019). From a theological perspective, Chisale (2020) has argued that a culture could exist within institutions such as the church that nurtures and protects patriarchy. This subsequently affects female pastors' entrance into such a context and their advancement (Wood, 2019). The challenge could also be rooted and still pushing for patriarchy, as Chisale (2020) has argued for the androcentric interpretations of religion codes, such as the bible, often pushing for gender bias. This often creates a culture that limits female pastors' advancement, especially in the church (Chifungo, 2015). In the United States, a study spanning the period 1998-2012 has observed a lack of acceptance of female pastors in the ministry, especially in large congregations and non-white sample communities (Hoegeman, 2017).

Another possible limitation to women's calling into so-called male jobs or careers could be the social construction around women's bodies. This can come in the form of what women can or cannot do and a possible source of gender discrimination (Eyigöra, Canb, ncesuluc, \& enold, 2020) and the perpetuation of gendered beliefs around careers (Wegemer \& Eccles, 2019). Gatrell's (2011) work flagging public hostility towards women who breastfeed at work is one such example. When women encounter difficulty at work, including stereotyping (of what they can or cannot do), this may create a negative experience of the job and be a subsequent deterrent towards certain career paths (Lu, Columbus, Fields, Melnitchouk, \& Cho, 2020). This has led to the need for a radical way of re-thinking, especially on how women's bodies (and their influence in culture) are framed and understood through nature and culture (Shilling, 2017). Compounded by this, religion also plays a part in framing what female pastors can or cannot do. This becomes a barrier that affects female pastors' career progression (Bannister \& Moyi, 2019), with religious and social systems playing a part (Womack et al., 2020).

\section{Research method}

The research adopted an interpretivist research philosophy hinging on a quantitative research approach and adopting an exploratory research design. In contemporary career research, such paradigms and methods are lauded in understanding complex issues surrounding modern careers (Beigi et al., 2020; Parker, Hapova, \& Arthur, 2009). The point of interest could be how female pastors navigate a maledominated terrain and social systems that affect their advancement (Kitada \& Harada, 2019). Such paradigms and methods adopted in this study assist in this regard.

\section{Sampling and research participants}

Fifteen participants were purposively selected for the study, relying on a snowball sampling approach (Patton, 2002). Given the networks that female pastors belong to, this allowed for an easy way to get hold of the participants. Further, the researchers also relied on referrals (Tongco, 2007). The study participants had all studied at the South African university-affiliated within the Seventh-day Adventist (SDA) Church, Helderberg College in Cape Town. The thinking here was that only those who have studied through church-affiliated institutions could likely serve as pastors in the ministry, as appears to be the practice. Consideration was also given to hearing from the female participants who may have studied at other SDA-affiliated institutions globally.

\section{Data collection}

The research team incorporated structured in-depth interviews as a research technique amongst the 10 participants. The data collection happened in three phases over a year-long process. Participants were interviewed at the start of 2017, mid-year and at the end of the year. The first contact during the interview process started with a question meant to put the participant at ease - 'Tell me about yourself' and this allowed the participants to be at ease. Thereafter, a series of questions guided from the literature were posed to the female pastors exploring career issues related to the formative years of their careers. The interviews were conducted either telephonically or in-person based on what was deemed convenient for the participant. The interviews lasted for an average of $50 \mathrm{~min}$ to an hour. For fear of possible identification, all participants requested for anonymity. The request for anonymity was granted and respected by the researchers.

\section{Data recording}

Interviews were audio-recorded and transcribed verbatim and stored on password-protected computers accessible only to the researchers. The interviews' recording protected the researchers against bias and provided a true record of what had been said during the interviews (McCormark, 2000). This also allowed the researchers to play back the interviews for the ease of data analysis.

\section{Strategies to ensure data integrity}

Some steps were taken to ensure data integrity. Firstly, using a narrative inquiry allowed a useful outlet for participants to be part of a process (concerning their career experience) to construct, re-construct and de-construct their personal stories (Savickas, 2012). This process assists in sense-making accompanying career stories (Taylor \& Savickas, 2016), 
especially those where gender issues feature (Pizzorno, Benozzo, \& Carrey, 2015). Secondly, collecting data and conducting interviews at three points during a calendar year helped ensure some form of depth in terms of data collection. Data were recorded and transcribed verbatim within $24 \mathrm{~h}$ of the interview at each of the three points.

Thirdly, after the data transcription process, a copy of the transcripts was sent to participants by email to verify their accuracy. This process took some time and was usually followed up by a telephone call. Finally, before and during the study, reflexivity was conducted to safeguard objectivity, avoid researcher bias and ensure sensitivity on how data were collected, analysed and represented (Taylor, Gibbs, \& Lewins, 2005). In doing so, we also took comprehensive notes at all critical stages of the research for additional depth and quality.

\section{Data analysis}

The researchers transcribed the interviews in Microsoft Word and then exported them into QSR International's NVivo 11, a useful data analysis and management software package that handles large volumes of text, graphic, audio and video data (Reuben \& Bobat, 2014). Narrative analysis procedures used in previous research internationally (McCormack, 2000) and career research in South Africa were utilised (Harry, Dodd, \& Chinyamurindi, 2019a, 2019b; Nyabvudzi \& Chinyamurindi, 2019). This analysis was based on the three levels of meaning-making (McCormack, 2000; Thornhill, Clare, \& May, 2004). The first level assisted in understanding the participating female pastors' career choice experiences based on their stories. A recursive process comprised re-reading each interview and listening to audio recordings.

Through this process, the researchers were able to identify markers within the transcripts and a basis for understanding each participant better (McCormack, 2000; Thornhill et al., 2004).

In turn, each transcript was grouped, based on participant stories, into a coherent format. The second level of the analysis process helped form useful categories around the data (Nachmias \& Nachmias, 1996). Through this grouping, the researchers could derive narratives across participant categorisations (Denzin \& Lincoln, 2000; Nachmias \& Nachmias, 1996). Finally, in level 3, the researchers analysed the content of the gathered narrative accounts using quotes based on consistencies across the participant stories and categorisations (McCormack, 2000)

\section{Findings}

Based on the outlined research design and methodology, including the analysis process, three main narratives emerged as a rationale or calling to the ministry expressed by the participating female pastors involved in the study:
1. The entrance to the pastoral ministry as a result of the voice of God

2. an entrance to the pastoral ministry as a result of the signs of God and

3. an entrance to the pastoral ministry because of the church's perceived shortage of female pastors. These findings emerged at level 1 of the data collection and are presented to understand issues that inform the early stages of career development. These findings are presented next.

\section{Answering the voice and signs of God}

The entrance into the pastoral ministry for the females participants to the study was attributed to the call of God through two manifestations in the form of: (1) the voice of God and (2) the signs of God.

Concerning the first, participants cited that through their faith activities such as personal devotions, meditation and prayer, they were drawn to enter the pastoral ministry. The attribution here was that such activities allowed them to hear the voice of God. One participant expressed this as:

'I got to a point when I was in prayer, and I could hear God calling me to something greater than I was. A path into a career that I never imagined I would enter, to be a pastor. The more I engaged in prayer and personal devotions, I felt drawn closer and closer. That for me, was how I answered the call, God speaking to me.' (Vern, black, 34 years)

Activities of faith feature again in the story of Laura with the usage of imagery:

'One of my favourite songs goes like - fill my cup Lord. I could relate, I was like an empty cup that needed to be filled. My concern though, was what next after the cup is filled. Then another song came to mind - broken and spilled out. I realised that God had been filling me all my life and now I needed to be broken and fill others. For me it meant considering a career in the pastoral ministry to fill other vessels.' (Laura, black, 33 years)

Other participants such as Jane highlighted the role of God's physical signs as confirming what they needed to do. Jane was at a cross-road between continuing her day job or studying and working as a pastor. What was interesting again was the role that the activities of faith played in pointing towards a direction. For Jane, this involved making a link to a Bible verse with her past and then making sense of all this to be attributed an answer to a question that she was seeking for:

'Reading the Bible one day, I read a verse in Jeremiah 6:16. "This is what the LORD says: Stop at the crossroads and look, ask for the ancient paths, ask where the good way is, and walk-in it" this verse helped me connect and make a critical path. The ancient path was where my spiritual values flourished, where I was there to help others. That verse for me made plain what was the desire of God. God to the ancient paths and charter a future path in becoming a pastor.' (Jane, black, 38 years)

Linked to this first narrative finding, it was the second finding, positioning significant others' roles and support to become a pastor. This finding, including illustrating stories and quotes, is presented next. 


\section{Support from significant others}

Significant others to the study, participants mostly included immediate family members, friends and community members. The desire for individual progression and, as found in the first narrative, the need to fulfil God's purpose, assisted in the path of entrance into a career as a pastor. For one participant, Mary, this appeared to be so:

\footnotetext{
'... my family was very supportive, this decision was going to have adverse effects for them and even influence my role within the family setup. I think what was key were two issues. What did God expect and want from me but also how this was to affect the family. Given the faith-based family setup I was brought up in - we knew that this was the right decision - the family bought into it as well.' (Mary, white, 40 years)
}

Another participant (Sue) echoed the support she received from significant others in studying for the pastoral ministry and sustenance for this study period. These significant others mostly comprised community members who also belonged to the same church:

'... a dedicated group of my community members from the church not only confirmed my entrance into the pastoral ministry but also my sustenance. These members continually encouraged me to think of the bigger picture, fulfilling the purpose of God. I told them of challenges I had around even paying fees to study. The same answer, think of the bigger picture, they encouraged me to follow this bigger picture and the sustenance thereof.' (Sue, black, 40 years)

A final participant (Moira) linked the significant others, as cited by Mary and Sue, by bringing another set of significant others, namely supporters, internationally through encouragement and career advice.

'I began writing to practicing female pastors mostly internationally for career advice on how one knows if this is the right career and spiritual path. The response was overwhelming from these international people [and some local] I gathered enough courage and strength to answer God's call for my life. The support also became critical, especially in moments when I wanted to give up. These friends helped me make the step into the door.' (Moira, black, 37 years)

Finally, the study participants' entrance to the pastoral ministry was also because of the need to challenge the status quo and have more female voice to a gendered space, the church.

\section{More female voice and representation}

This finding appears to be rooted in how participants made sense of their environment and their desire to be part of a change process. Predominantly in their context, the majority who serve in the ministry happen to be male pastors. One participant, Basey, bemoaned the under-representation of women into the ministry and how this framed (despite being early) her decision to also consider the pastoral ministry as a calling and space where she can practice as a female:

'Female voices are missing from the pulpit. Female voices are generally missing. So having been brought up in the church, I also began to question this. From this questioning, I realised the answer can be through me as a female, stepping up.' (Basey, black, 45 years)

The views echoed by Basey are similar to those of Kate; a distinguishing thread though is how support for significant others (including use of scripture reference) led her to position her need to go into the ministry despite the male domination:

'I was at my lowest point - questioning whether should I or should I not? Some friends came together and impressed upon me the need to consider the pastoral ministry. The model, the biblical character in Esther and her rise, claim God's purpose and will. Like Esther, I felt I needed to rise against patriarchy - for such a time as this. The decision had been made, I took the steps from thereon.' (Kate, black, 34 years)

Finally, Jill brought in the idea of the need for more female voice and representation in narrating her life story. Jill recalled that while growing up in the church, she always noticed there was a delineation of role and activity by gender:

'It was clear, the Black African church had a clear separation of duties and responsibilities. As a young girl, I could see all this. You grow up in a church system where you are basically programmed to know what you can or cannot do. The awakening for me was motivated by the need to break out of the programmed pattern. Challenging this way of thinking actually led me to a career in the ministry despite having tried other things.' (Jill, black, 36 years)

Table 1 provides further quotes to support the findings presented.

\section{Discussion}

The purpose of this study was to explore the issues affecting female pastors' career choice into ministry. The findings draw on the role that elements of faith, calling, spirituality and religiosity play in career choice formation. Intriguingly, this has been an area that has not received much empirical attention within a South African work psychology perspective despite the noted shift of women in maledominated professions (Albrecht et al., 2018; Gagnon \& Sandoval, 2020).

Furthermore, the findings highlight the role of individual and institutional forces in exploring issues of career choice. For example, the study participants highlighted their desire to frame their career path within an institution (the church) and a socio-cultural milieu. Another example of the contextual meaning of knowing why the dimension in the findings was the role of intersectionality in forming career choice decisions. This presents and supports work findings that women entering male-dominated careers experience complexities (Hasunuma, 2019). Our findings support previous work in other industries that position patriarchy's role and the thinking around this as limiting women's career advancement (Bannister \& Moyi, 2019). Our study illustrates how this happens within religious systems. Despite this experience being a limitation (Womack et al., 2020) in our 
TABLE 1: Narratives and quotes of female pastors $(n=10)$.

Narrative finding
antrance to the pastoral ministry as
signs of God
Entrance to the pastoral ministry as
a result of support from significant
others
Quote

'God does not call the qualified, God qualifies the called. This has been my motto, I was not qualified but I had a calling. The calling of God has qualified me.' (Mercy, black person, 34 years)

'I asked for a sign. I wanted to know if I should leave my current job and consider being a pastor. The sign for me came in that no matter how much I tried. Things just did not work to plan. It was like pushing against a wall. For me this was the sign I needed. I quit my job and focussed on ministry. It has been tough yes, but I am at my happiest state ever.' (Jill, black person, 36 years)

'Does God speak in mysterious ways? Yes, he does. For me, it was a clear and audible voice to follow this path. I resisted but the more I did this, the more they grew louder and louder. I can say I am at the place where I should be right now.' (Kate, black person, 34 years)

'my number one fans are my family, they really had to put up a lot with me growing up. The best advice and support I ever received what around the decision to go and study theology and subsequently in my current ministry.' (Vern, black person, 34 years)

'Coming from the township context, you have an army of supporters. I remember preaching as a youth and some ladies from the church called me and encouraged me to consider a ministry career. This is something I always wanted and I guess the encouragement reinforced this.' (Sue, black person, 40 years)

'my father before he died encouraged me to follow my dreams and not let anyone stop me. My current work really is an expression of this encouragement, I think this will always be the case.' (Basey, black person, 45 years)

Entrance to the pastoral ministry because of the need to challenge the status quo and give more female voice to a gendered space, the church

'I feel the patriarchy system has damaged so many lives, especially those of females and those not powerful. There was a need for a form of activism. An activism that does not fight the church but rather works with the church. I found motivation in several young females from all over our Southern African region going to study theology. Yes, some could not pastor afterward, but they were taking the first steps of this activism. The next wave for me is to see more and more females rising in numbers to work in the ministry.' (Mercy, black person, 34 years) 'So if we can challenge those who think a woman's place is in the kitchen. Why can we not challenge those that believe a woman cannot preach or lead a church? The idea is the same for me. From a young age, I knew I could preach better than some males. For me, the ministry began at a young age. The full expression was needed in my adult years. To serve as a pastor, not as a female pastor but just a pastor. My gender matters not. My ministry and effort is what matters.' (Moira, black person, 37 years)

'There is a gap in the church, infect it is a ministry. This is a ministry that can only be filled by females. I think given the demographics of the country, we have more females. There is a need for more female taking position in ministry.' (Laura, black person, 38 years)

work, it appeared to be a driver that allowed the women participants to consider entering the pastoral ministry, challenging the status quo. This potentially illustrates how women's career experiences differ from their male counterparts (Hancock \& Hums, 2016). Despite this, through finding the need for more female representation, there may be a need to challenge the status quo from a position of contribution rather than the perception of a challenge to male spiritual authority (Oom-Dove, 2018). This can encourage more women to join the ministry bearing in mind the needs on the ground. These needs could be provided for emotional support (Hope et al., 2017) and community counselling (Hoga et al., 2013).

Although a distinction could be made, issues like the lack of women's participation in professions like the ministry can and should also be viewed based on two issues. Firstly, through the first finding of answering God's voice and call, the roles of aspects of faith, calling, spirituality and religiosity are important aspects of an individual's life (Amoateng, 2020; ed. Ewest, 2018), which also manifest publicly. This study, placing focus on career choice formation, highlights not only this importance but also the factors that inform individual decision-making around this.

The study makes some important contributions. Firstly, the study advances understanding of the processes that accompany how women usually enter male-dominated professions. This adds to the already growing body of the literature (Khubisa \& Reddy, 2017) and is also a potential contribution, especially for IOP practitioners. The implication here, especially considering issues of faith, calling, spirituality and religiosity, is that IOP practitioners and career counsellors may need to bear in mind these issues as they work with clients and contexts where these feature. This fits in with the suggestion for IOP practitioners to be aware of the context in which people live and work (Van Zyl, Deacon, \& Rothmann,
2010). We add to this, considering that beliefs such as those of faith, calling, spirituality and religiosity feature in how individuals frame the experience of work (ed. Neal, 2013), and thus IOP must also be responsive. There is also a need for an awareness of understanding especially what individuals believe to be a part of providing this needed psycho-social support, especially for IOP practitioners and career counsellors.

\section{Implications}

There is a need for IOP as a discipline, including the practitioners who work in it, to be cognisant of aspects of faith, calling, spirituality and religiosity - as these feature in how individuals frame aspects of individual career choice and career development. The issue may be for such practitioners to support and provide some empathy for those factors provided by those they counsel. For instance, in this study, findings such as answering God's voice and signs, as shown, form critical individual reasons for career choice decisions and affirmations.

The study places importance on understanding how industrial psychologists may need to pay attention to issues concerning aspects of faith, calling, spirituality and religiosity. These issues are deemed critical, especially to those practitioners interested in sub-fields such as career management. Through the findings of this study, a glaring point needs attention to consider this practitioner audience. Work psychology as a field will require practitioners who spend most of their time with people to consider the communities they reside in and work in (Van Zyl et al., 2010). Such IOP practitioners, we argue, may need to be aware of the range of issues (including aspects of faith, calling, spirituality and religiosity) based on an effectual and efficient praxis and practice.

To an outsider, who may not believe in God, this may be nebulous. However, the support needed by an IOP 
practitioner is to affirm this to be part of individual career pathing and a good example of how values (such as those of faith, calling, spirituality and religiosity) feature in such career paths. Another implication of the study, borrowing from the second finding, may be to encourage individuals engaged in under-represented professions to seek guidance and psycho-social support from significant others. This can be performed by assisting community members in their role as portals of information that could potentially assist individual career pathing. Finally, using the third finding of this research, career counsellors may need to empower women who enter male-dominated work spaces with strategies on how they can survive in such contexts. In countries like South Africa that are very patriarchal, this may be something very critical to address. Training on resilience and coping techniques becomes necessary because of this.

\section{Limitations of the study}

Some limitations exist with this work. Firstly, sampling issues feature as a concern. The study participants belong to a marginalised professional group that is a dominant area of mostly male pastors. The researchers not only had difficulties in accessing this sample but also in getting the female pastors to share their stories. This presented both an aspect of difficulty and also an opportunity. The participating female pastors in this study should be lauded for their attempt to speak out and to challenge the status-quo. This does not take away the presented sampling limitation. Secondly, the research narrows focus on those female pastors who have studied and completed their qualifications for the pastoral ministry. There could be other female pastors who have intended to complete their studies but have failed to do so. Their voices, though not captured in this research, warrant further attention. Access to the sample was only through those who have completed their pastoral studies. Thirdly, the study focuses only on female pastors who have come through the SDA church, as such experience is framed only within this one-church context. This helped us as narrative researchers considering debates and issues of controlling for agency-context issues as they have been illustrated to feature greatly in exploratory narrative work conducted previously (Harry et al., 2019a, 2019b; Nyabvudzi \& Chinyamurindi, 2019). All this dovetails into some insights to inform future research.

\section{Future research}

Future research can be proposed based on this study. Firstly, we call on fellow researchers and practitioners to engage in work that deals with those concepts, experiences and practices that do not often receive empirical attention, especially within IOP. We note issues of faith, calling, spirituality and religiosity to be an example of such. To some, these issues may be nebulous and often lacking in supporting ideals of empiricism, which often results in them being avoided. However, as we experienced in our study, these issues remain important to some individuals based on their role as anchors of values. This positions the need for further research into this. Remembering also the caution that researchers and practitioners need to be aware of the changing socio-economic environment and its relation to work (Savickas et al., 2009), the role of issues of faith, calling, spirituality and religiosity becomes heightened in all this. The need is for researchers' and practitioners' work that is contextually situated (Maree, 2016a; Watson, 2013).

Future research could also be longitudinal, tracing not only issues of career choice but also seeking to understand other important issues such as: (1) career success, (2) career barriers, (3) resolution tactics to barriers, (4) dealing with career shocks and (5) the role of career adaptability in the career paths where issues of faith, calling, spirituality and religiosity feature. Finally, future research could be comparative between male and female pastors, which can be informed by possible differences in career experiences by gender (Gledhill \& Harwood, 2015). This could be looking at male and female pastors' experiences in terms of the pastoral ministry, the role of culture in how male and female pastors are treated and even exploring aspects of human resources management practices organisationally (e.g. compensation or training opportunities) concerning male and female pastors. The focus here is on understanding institutions' role in constructing boundaryless careers (Tams \& Arthur, 2010; Thornton, Oscasio, \& Lounsbury, 2012).

\section{Acknowledgements}

The researchers acknowledge the role of the participants in sharing their stories with us.

\section{Competing interests}

The authors have declared that no competing interest exists.

\section{Authors' contributions}

W.T.C. and R.H. equally contributed to the research including the writing of this article.

\section{Ethical consideration}

The research adhered to ethical guidelines. Firstly, ethical clearance was applied for and granted at the participating institution where the researchers are based. The ethical clearance number granted for this was RAS101SCHI01. Secondly, permission was solicited and granted from participants to the study. The participants all emphasised the need for anonymity. The researchers emphasised the fact that pseudonyms would be utilised throughout the research. Thirdly, the researchers also adhered to other issues concerning ethical considerations that included voluntary participation, informed consent and the right to withdraw at any point in the research. Finally, after transcribing the interviews, copies were sent back to the participants as a way of verification. Participants were free to add or correct the transcriptions and return them to the researchers. 


\section{Funding information}

This research received no specific grant from any funding agency in the public, commercial or not-for-profit sectors.

\section{Data availability statement}

Data sharing is not applicable to this article as no new data were created or analysed during this study.

\section{Disclaimer}

The views and opinions expressed in this article are those of the authors and do not necessarily reflect the official policy or position of any affiliated agency of the authors.

\section{References}

Abu-Hammad, S., Elsayed, S.A., Nourwali, I., Abu-Hammad, O., Sghaireen, M. Abouzaid, B.H., \& Dar-Odeh, N. (2020). Influence of gender on career expectation of oral and maxillofacial surgeons. Journal of Cranio-Maxillo-Facial Surgery, 48(4), 458-462. https://doi.org/10.1016/j.jcms.2020.02.023

Albrecht, J., Bronson, M.A., Thoursiec, P.S., \& Vroman, S. (2018). The career dynamics of high-skilled women and men: Evidence from Sweden. European Economic Review, 105, 83-102. https://doi.org/10.1016/j.euroecorev.2018.03.012

Amoateng, A.Y. (2020). Does religion affect political engagement of the youth at the tertiary level of education? The case of undergraduate students at a South African university. Theologia Viatorum, 44(1), 1-11. https://doi.org/10.4102/TV.v44i1.21

Astin, H.S. (1984). The meaning of work in women's lives: A socio-psychological model of career choice and work behavior. The Counseling Psychologist, 12(3/4), 117-126. https://doi.org/10.1177/0011000084124002

Bannister, M., \& Moyi, E. (2019). Domestic gender-based violence and the potential offered by empowerment initiatives: The case of Makhokho, Western Kenya. Women's Studies International Forum, 77, 1-8. https://doi.org/10.1016/ Women's Studies
j.wsif.2019.102295

Beigi, M., Nayyeri, S., \& Shirmohammadi, M. (2020). Driving a career in Tehran: Experiences of female Internet taxi drivers. Journal of Vocational Behaviour, 116, 1-16. https://doi.org/10.1016/j.jvb.2019.103347

Betz, N.E., \& Fitzgerald, L.F. (1987). The career psychology of women. Orlando, FL: Academic Press.

Beukes, I., \& Botha, E. (2013). Organisational commitment, work engagement and meaning of work of nursing staff in hospitals. South African Journal of Industria Psychology, 39(2), 1-10. https://doi.org/10.4102/sajip.v39i2.1144

Bumgardner, L. (2015). Adventist women clergy: Their call and experience. Journal of Applied Christian Leadership, 9(2), 40-53.

Burger, D.H., Crous, F., \& Roodt, G. (2012). Exploring a model for finding meaning in the changing world of work (Part 2). South African Journal of Industrial Psychology, 38(1), 1-11. https://doi.org/10.4102/sajip.v38i1.968

Butler, A. (2007). Women in the church of God in Christ: Making a sanctified world. Chapel Hill, NC: The University of North Carolina Press.

Chifungo, P. (2015). Women and church: A case study of CCAP. Nkhoma Synod, Malawi. In E. Mouton, G. Kapuma, L. Hansen, \& T. Togom (Eds.), Living with dignity: African perspectives on gender equality (pp. 147-157). Stellenbosch: Sun Press.

Chinyamurindi, W.T. (2016a). Using narrative analysis to understand factors influencing career choice amongst a sample of distance learning students in South Africa. South African Journal of Psychology, 46(3), 390-400. https://doi org/10.1177/0081246315623662

Chinyamurindi, W.T. (2016b). A narrative investigation into the meaning and experience of career success: Perspectives from women participants. South African Journal of Human Resource Management, 14(1), 1-11. https://doi. org/10.4102/sajhrm.v14i1.659

Chisale, S.S. (2020). 'Deliver us from patriarchy': A gendered perspective of the Evangelical Lutheran Church in Southern Africa and implications for pastoral care. Verbum et Ecclesia, 41(1), 1-8. https://doi.org/10.4102/ve.v41i1.2003

Cooper, R. (1995). The firemen: Immaculate manhood. Journal of Popular Culture, 28(4), 139-171. https://doi.org/10.1111/j.0022-3840.1995.1395768.x

Cox, K., \& Diamant, J. (2018). Black men are less religious than black women, but more religious than white women and men. Retrieved from www.pewresearch.org/ fact-tank/2018/09/26/black-men-are-less-religious-thanblack-women-but-morereligious-than-white-women-and-men

Denzin, N.K., \& Lincoln, Y.S. (2000). Handbook of qualitative research. London: Sage.

Ewest, T. (Ed.) (2018). Faith and work: Christian perspectives, research and insights into the movement. In L.W. Fry (Series Ed.), Advances in workplace spirituality: Theory, research and application (pp. 247-264). Charlotte, NC: Information Age Publishing.

Eyigöra, H., Canb, I.H., Incesuluc, A., \& Şenold, Y. (2020). Women in otolaryngology in Turkey: Insight of gender equality, career development and work-life balance. American Journal of Otolaryngol, 41(1), 1-5. https://doi.org/10.1016/ j.amjoto.2019.102305
Fouché, E., Rothmann, S., \& Van der Vyver, C. (2017). Antecedents and outcomes of meaningful work among school teachers. South African Journal of Industrial Psychology, 43, 1-10. https://doi.org/10.4102/sajip.v43i0.1398

Gagnon, R.J., \& Sandoval, A. (2020). Pre-college STEM camps as developmental context: Mediational relations between gender, career decidedness, socioemotional development, and engagement. Children and Youth Services Review, 108, 1-9. development, and engagement. Children and Youth
https://doi.org/10.1016/j.childyouth.2019.104584

Gatrell, C. (2011). Policy and the pregnant body at work: Strategies of secrecy, silence and supra-performance. Gender, Work \& Organization, 18(2), 158-181. https:// doi.org/10.1111/j.1468-0432.2009.00485.x

Gledhill, A., \& Harwood, C. (2015). A holistic perspective on career development in UK female soccer players: A negative case analysis. Psychology of Sport and Exercise, 21, 65-77. https://doi.org/10.1016/j.psychsport.2015.04.003

Graham, E. (1995). From space to woman-space. Feminist Theology, 3(9), 11-34. https://doi.org/10.1177/096673509500000902

Hancock, M.G., \& Hums, M.A. (2017). A 'leaky pipeline'?: Factors affecting the career development of senior-level female administrators in NCAA Division I athletic departments. Sports Management Review, 19(2), 198-210. https://doi. org/10.1016/j.smr.2015.04.004

Harry, T., Dodd, N., \& Chinyamurindi, W.T. (2019a). Using narratives to understand the experience of career success. Southern African Business Review, 23(November), 1-27.

Harry, T., Dodd, N., \& Chinyamurindi, W.T. (2019b). Telling tales: Using narratives and story-telling to understand the challenges faced by a sample of self-initiated expatriates in South Africa. Journal of Global Mobility, 7(1), 64-87. https://doi. org/10.1108/JGM-05-2018-0024

Hasunuma, L. (2019). Beyond formal representation: Case studies of women's participation in civil society in Japan. Women's Studies International Forum, 72, 1-8. https://doi.org/10.1016/j.wsif.2018.10.001

Hoegeman, C. (2017). Job status of women head clergy: Findings from the national congregations study, 1998, 2006, and 2012. Religious, 8(154), 1-16. https://doi. org/10.3390/rel8080154

Hoga, L.A.K., Rodolpho, J.R.C., Penteado, P.E., Borges, A.L.V., \& Alvarez, R.E.C. (2013). Religiosity and sexuality: Counseling provided by Brazilian Protestant pastors Sexual \& Reproductive Healthcare, 4(2), 57-63. https://doi.org/10.1016/j. srhc.2013.04.001

Hope, M.O., Assari, S., Cole-Lewis, Y.C., \& Caldwell, C.H. (2017). Religious social support, discrimination, and psychiatric disorders among Black adolescents. Race and Social Problems, 9(2), 102-114. https://doi.org/10.1007/s12552-0169192-7

Iddrisu, M., Aziato, L., \& Dedey, F. (2019). A qualitative study on coping strategies of young women living with breast cancer in Ghana. International Journal of Africa Nursing Sciences, 11, 1-8. https://doi.org/10.1016/j.ijans.2019.100173

Jodamus, J. (2017). Paul, the 'real' man: Constructions and representations of masculinity in 1 Corinthians. Journal of Gender and Religion in Africa, 23(2), 68-94. https://doi.org/10.14426/ajgr.v23i2.30

Khubisa, T., \& Reddy, S. (2017). Religio-cultural ideals of women's body shapes: A review of black women's engagement with bodybuilding. Journal of Gender and Religion in Africa, 23(2), 1-23. https://doi.org/10.14426/ajgr.v23i2.27

Kincheloe, J.L., \& McLaren, P. (2002). Rethinking critical theory and qualitative research. In Y. Zou \& E.T. Trueba (Eds.), Enthnography and schools: Qualitative approaches to the study of education (pp. 285-326). Lanham, MD: Rowman \& Littlefield.

Kitada, M., \& Harada, J. (2019). Progress or regress on gender equality: The case study of selected transport STEM careers and their vocational education and training in Japan. Transportation Research Interdisciplinary Perspectives, 1, 1-9. https://doi.org/10.1016/j.trip.2019.100009

Koekemoer, E., \& Mostert, K. (2010). An exploratory study of the interaction between work and personal life: Experiences of South African employees. South African Journal of Industrial Psychology, 36(1), 1-15. https://doi.org/10.4102/sajip. v36i1.801

Lazar, A., Davidovitch, N., \& Coren, G. (2016). Gender differences in calling and work spirituality among Israeli academic faculty. Journal of International Education Research, 12(3), 87-98. https://doi.org/10.19030/jier.v12i3.9744

LoRusso, J.D. (2017). Spirituality, corporate culture, and American business. New York, NY: Bloomsbury Academic Publishing.

Lu, P.W., Columbus, A.B., Fields, A.C., Melnitchouk, N., \& Cho, N.L. (2020). Gender differences in surgeon burnout and barriers to career satisfaction: A qualitative exploration. Journal of Surgical Research, 247, 28-33. https://doi.org/10.1016/ j.jss.2019.10.045

Maree, J.G. (2016a). Career construction counselling with a mid-career black male. Career Development Quarterly, 64(1), 20-35. https://doi.org/10.1002/ cdq.12038

Masola, N.J., Sigida, S.T. \& Khorommbi, E.M. (2019). Spiritual diagnostic criteria in an African setting: The case of baruti in Limpopo province, South Africa. Theologid Viatorum 43(1), 1-5. https://doi.org/10.4102/TV.v43i1.24

McCormack, C. (2000). From interview transcript to interpretative story: Part 1. Viewing the transcript through multiple lenses. Field Methods, 26(1), 282-297. https://doi.org/10.1177/1525822X0001200402

Mozahem, N.A., Ghanem, C.M., Hamieh, F.K., \& Shoujaa, R.E. (2019). Women in engineering: A qualitative investigation of the contextual support and barriers to their career choice. Women's Studies International Forum, 74, 127-136. https:// doi.org/10.1016/j.wsif.2019.03.014 
Mujinga, M. (2020). Rising against all odds: An analysis of the leadership experiences of three female clergy in the Methodist Church in Zimbabwe. HTS Teologiese Studies/Theological Studies, 76(2), 1-10. https://doi.org/10.4102/ Teologiese Studie
hts.v76i2.5864

Mupangwa, T., \& Chirongoma, S. (2020). The challenges of being a female pastor: A case of the Apostolic Faith Mission in Zimbabwe. HTS Teologiese Studies/ Theological Studies, 76(2), 1-10. https://doi.org/10.4102/hts.v76i2.5838

Nachmias, F.C., \& Nachmias, D. (1996). Research methods in the social sciences. New York, NY: Worth Publishers.

Neal, J. (Ed.). (2013). Handbook of faith and spirituality in the workplace. New York, NY: Springer.

Nyabvudzi, T., \& Chinyamurindi, W.T. (2019). The career development processes of women refugees in South Africa: An exploratory study. South African Journal of Industrial Psychology, 45, 1-11. https://doi.org/10.4102/sajip.v45i0.1662

Nyabvudzi, T.G. \& Chinyamurindi, W.T. (2020). Career development barriers post-settlement affecting women refugees: Implications for human capital development. Gender Questions, 8(1), 1-26.

Oom-Dove, S. (2018). Revivalist women's submission: Women's spiritual authority, biblical feminism and cosmofeminism. Women's Studies International Forum, 67, 118-127. https://doi.org/10.1016/j.wsif.2017.09.005

Parker, P., Khapova, S.N., \& Arthur, M.B. (2009). The intelligent career framework as a basis for interdisciplinary inquiry. Journal of Vocational Behavior, 75(3), 291-302. https://doi.org/10.1016/j.jvb.2009.04.001

Patton, M.Q. (2002). Qualitative research and evaluation methods (3rd edn.). Thousand Oaks, CA: Sage.

Phiri, I.A. (2009). Major challenges for African women theologians in theological education (1989-2008). International Review of Mission, 98(1), 105-119. https:// doi.org/10.1111/j.1758-6631.2009.00009.x

Pizzorno, M.C., Benozzo, A., \& Carey, N. (2015). Narrating career, positioning identity and constructing gender in an Italian adolescent's personal narratives. Journal of Vocational Behaviour, 88, 195-204. https://doi.org/10.1016/j.jvb.2015.03.002

Reilly, N. (2007). Cosmopolitan feminism and human rights. Hypatia: A Journal of Feminist Philosophy, 22(4), 180-198. https://doi.org/10.1111/j.1527-2001.2007. tb01327x

Reuben, S., \& Bobat, S. (2014). Constructing racial hierarchies of skill-experiencing affirmative action in a South African organisation: A qualitative review. South African Journal of Industrial Psychology, 40(1), 1-12. https://doi.org/10.4102/ sajip.v40i1.1158

Roberston, M. (2017). Querying scholarship on Christianity and queer sexuality: Reviewing nuances and new directions. Journal of Gender and Religion in Africa, 23(2), 125-144. https://doi.org/10.14426/ajgr.v23i2.31

Savickas, M.L. (2005). Theory and practice of career construction. In S.D. Brown \& R.W. Lent (Eds.), Career development and counseling: Putting theory and research to work (pp. 42-70). Hoboken, NJ: John Wiley \& Sons.

Savickas, M.L. (2012). Life design: A paradigm for the 21st century. Journal of Counseling and Development, 90, 13-19. https://doi.org/10.1016/j.jvb.2009.04.004

Savickas, M.L., Nota, L., Rossier, J., Dauwalder, J.-P., Duarte, M.E., Guichard, J., Van Vianen, A.E.M. (2009). Life designing: A paradigm for career construction in the 21th century. Journal of Vocational Behavior, 75(3), 239-250.
Savickas, M. (2012). Life design: A paradigm for career intervention in the 21st century. Journal of Counseling \& Development, 90, 13-19.

Shilling, C. (2017). Body pedagogics: Embodiment, cognition and cultural transmission. Sociology, 51(6), 1205-1221. https://doi.org/10.1177/0038038516641868

Sturges, J. (2019). In God's name: Calling, gender and career success in religious ministry. Gender Work Organization, 26(11), 1-17. https://doi.org/10.1111/ gwao.12424

Tams, S., \& Arthur, M.B. (2010). New directions for boundaryless careers: Agency and interdependence in a changing world. Journal of Organizational Behavior, 31(5), 629-646. https://doi.org/10.1002/job.712

Taylor, C., Gibbs, G.R., \& Lewins, A. (2005). Quality of qualitative analysis. Retrieved from http://onlineqda.hud.ac.uk/Intro_QDA/qualitative_analysis.php

Taylor, J., \& Savickas, S. (2016). Narrative career counselling: My career story and pictorial narratives. Journal of Vocational Behaviour, 97, 68-77. https://doi. org/10.1016/j.jvb.2016.07.010

Thornhill, H.L., Clare, L., \& May, R. (2004). Escape, enlightenment and endurance: Narratives of recovery from psychosis. Anthropology and Medicine, 11(2), 181-199. https://doi.org/10.1080/13648470410001678677

Thornton, P.H., Oscaio, W., \& Lounsbury, M. (2012). The institutional logics perspective: A new approach to culture, structure, and process. New York, NY: Oxford University Press.

Tongco, D.C. (2007). Purposive sampling as a tool for informant selection. Ethnobotany Research \& Applications. A Journal of Plants, People and Applied Research, 5, 147-158. https://doi.org/10.17348/era.5.0.147-158

Van Zyl, L.E., Deacon, E., \& Rothmann, S. (2010). Towards happiness: Experiences of work-role fit, meaningfulness and work engagement of industrial/organisational psychologists in South Africa. South African Journal of Industrial Psychology, 36(1) 1-10. https://doi.org/10.4102/sajip.v36i1.890

Wang, G., Holmes, M., Devine, R., \& Bishoff, J. (2019). CEO gender differences in careers and the moderating role of country culture: A meta-analytic investigation. Organizational Behavior and Human Decision Processes, 148, 30-53. https://doi. org/10.1016/j.obhdp.2018.04.002

Watson, M. (2013). Deconstruction, reconstruction, co-construction: Career construction theory in a developing world context. Indian Journal of career and Livelihood Planning, 2, 3-14.

Wegemer, C.M., \& Eccles, J.S. (2019). Gendered STEM career choices: Altruistic values, beliefs, and identity. Journal of Vocational Behavior, 110, 28-42. https://doi. org/10.1016/j.jvb.2018.10.020

Willemse, M., \& Deacon E. (2015). Experiencing a sense of calling: The influence of meaningful work on teachers' work attitudes. South African Journal of Industrial Psychology, 41(1), 1-9. https://doi.org/10.4102/sajip.v41i1.1274

Womack, J.M., Duncan, G., \& Pillay, J. (2020). The relevance and necessity of contextualising theological education and ministerial formation in South Africa. Verbum et Ecclesia, 41(1), 1-8. https://doi.org/10.4102/ve.v41i1.2059

Wood, H.J., (2019). Gender inequality: The problem of harmful, patriarchal, traditional and cultural gender practices in the church. HTS Theological Studies, 75(1), 1-8. https://doi.org/10.4102/hts.v75i1.5177

Wright, L.S., Branscum, P., Maness, S., Larson, D., Taylor, E.L., Mateux, L., \& Cheney, M.K. (2019). Parents' beliefs of the Black Church's role in teen pregnancy prevention. Journal of Adolescence, 72, 52-63. https://doi.org/10.1016/ j.adolescence.2019.02.004 